\title{
Undervisningsprogram i videregående skoler om psykiske plager: Effekter på elevers hjelpsøking og psykiske helse
}

\author{
Bror Just Andersen ${ }^{1,2}$, Rune Johansen ${ }^{1}$ og Erik Nord ${ }^{1}$ \\ 1) Nasjonalt folkehelseinstitutt, divisjon for psykisk helse \\ 2) Vestre Viken HF, Barum DPS \\ Korrespondanse: bror.just.andersen@vestreviken.no
}

\begin{abstract}
SAMMENDRAG
Det primærforebyggende programmet "VIP" - Veiledning og Informasjon om Psykisk helse - gjennomføres overfor elever i første klasse i videregående skoler. VIPs mål er å fremme psykisk helse ved å øke elevenes kunnskapsgrunnlag om psykiske helse, å forbedre de unges evne til gjenkjennelse av signaler på psykiske lidelser og å senke terskelen for å søke hjelp. Vi evaluerer VIP ved å sammenlikne elever $i$ et utvalg av skoler i Akershus der intervensjonen ble gjennomført (intervensjonsgruppe), med elever i et utvalg av skoler i Vestfold som ikke fikk intervensjonen (kontrollgruppe). Vi har tidligere funnet at programmet på helt kort sikt har effekter både på generelle kunnskaper om psykisk helse og på kunnskaper om hjelpeapparatet. I denne artikkelen har vi vist at det etter 6 og 12 måneder synes å være en liten effekt på hjelpsøking. Innvirkningen på dagliglivet blant de som faktisk har problemer er positiv (12\% bedre utvikling etter 12 måneder) men ikke statistisk signifikant. Derimot har vi funnet statistisk signifikante effekter på totalskåren i SDQ-Nor (Cohens $\mathrm{d}=0,15)$, problemnivå med jevnaldrende $(\mathrm{d}=0,31)$ og angst etter 12 måneder $(\mathrm{d}=0,37)$. Vi finner dette bemerkelsesverdig gitt VIP-intervensjonens moderate omfang og den store sammenhengen som VIP-programmet forekommer i. Effektene er ikke veldig store, men selv moderate eller små bidrag til økt kunnskap og bedre mestring gjennom VIP-programmet vil være forsvarlig hvis det oppnås med tilsvarende lave kostnader. En nærmere analyse av programmets kostnader vil således være av interesse.
\end{abstract}

\section{INNLEDNING}

Mellom 15 og 20\% av alle ungdommer i Norge har psykiske problemer som går ut over deres fungeringsevne (1-3). Det er evidens for at tidlig hjelp vil kunne gi unge med psykiske lidelser bedre muligheter og minske sjansen for gjentatte, alvorlige sykdomsperioder (4-8). Samtidig er det rimelig å anta at mer kunnskap blant de unge om psykiske lidelser øker sjansene for at tidlig hjelp vil bli søkt.

En rekke primærstudier og forskningsoppsummeringer internasjonalt dokumenterer effekter av forebyggende intervensjoner på området psykisk helse. De positive funnene, både for befolkningsrettede tiltak og tiltak rettet mot høyrisikogrupper, gjelder områder som angst, depresjon, selvmord, atferdsproblemer og mobbing. De er hovedsakelig knyttet til endring av kunnskap, oppmerksomhet, holdninger/stigma og atferd (930). Nasjonalt er det imidlertid få studier av god kvalitet på dette området. En studie omhandler angst mens de andre i hovedsak retter seg mot atferdsproblematikk (31-36).

Det primærforebyggende programmet "VIP" - Veiledning og Informasjon om Psykisk helse - ble startet etter initiativ fra brukerrådet på Blakstad sykehus i 1999. Det utøves overfor elever i første klasse i videregående skoler og hadde per januar 2009 56\% dekning blant slike skoler i Norge (37). Blant de primære målene finner vi:
1. Å øke elevenes kunnskapsgrunnlag om psykisk helse og på den måten gjøre elevene bedre i stand til å ta vare på sin egen psykiske helse.

2. Å forbedre de unges evne til gjenkjennelse av signaler på psykiske lidelser.

3. Å senke terskelen for å søke hjelp.

Intervensjonen består av muntlig og skriftlig informasjon til både lærere og elever, for de sistnevntes vedkommende bl.a. i form av 3-5 skoletimer der det arbeides med et veilednings- og oppgavehefte. Heftet dreier seg om helsefremmende og sykdomsforebyggende tiltak. Elevene lærer om hva som regnes som psykiske problemer og lidelser. For nærmere opplysninger, se (58) og intervensjonens nettside (37).

Vi evaluerer VIP med hensyn til effekter på de tre ovennevnte resultatmålene og psykisk helse ved å sammenlikne elever i et utvalg av skoler der intervensjonen ble gjennomført (intervensjonsgruppe), med elever i et utvalg av skoler som ikke fikk intervensjonen før etter forskningsprosjektets avslutning (kontrollgruppe).

Kunnskaps- og holdningsendringer fra umiddelbart før (tidspunkt t0) til 2-3 uker etter intervensjon (tidspunkt 1 ) er rapportert $i$ en annen artikkel i dette temanummeret (58). Der er også metoder mer detaljert rapportert enn i det følgende. Vi fant moderat til sterke, positive virkninger på kjennskap til psykiske lidelser, generell kunnskap om psykisk helse, evne til kopling av symptomer til diagnoser, kunnskap om hjelpeapparatet 


\begin{tabular}{|c|c|c|c|c|c|c|}
\hline & t 0 & & $\mathrm{t} 1$ & $\mathrm{t} 2: 6 \mathrm{mnd}$ & t $3: 12$ mnd & $\mathrm{t} 4: 24 \mathrm{mnd}$ \\
\hline Gruppe 1 & Pretest & Intervensjon & Posttest 1 & Posttest 2 & Posttest 3 & Posttest 4 \\
\hline Gruppe 2 & Pretest & & Posttest 1 & Posttest 2 & Posttest 3 & Posttest 4 \\
\hline Gruppe 3 & & Intervensjon & Posttest 1 & Posttest 2 & Posttest 3 & Posttest 4 \\
\hline Gruppe 4 & & & Posttest 1 & Posttest 2 & Posttest 3 & Posttest 4 \\
\hline
\end{tabular}

Figur 1. Prosjektets forskningsdesign.

generelt og kunnskap om hjelpeapparatet i nærmiljøet.

I denne artikkelen estimerer vi virkninger av intervensjonen på oppmerksomhet på problemer blant venner og klassekamerater, uttrykte holdninger til og faktisk atferd hvis problemer forekommer og symptomforekomst ett år etter intervensjonen. Vi antar at intervensjonen kan gi umiddelbare effekter på oppmerksomhet på problemer og på uttrykte holdninger, men at effekter på hjelpsøkeradferd i beste fall kan observeres etter 6 måneder og effekter på symptomnivå i beste fall kan observeres etter 12 måneder. Disse hypotesene spesifiseres på konkrete variable etter redegjørelsen for disse nedenfor.

\section{MATERIALE OG METODER}

\section{Utvalg}

Intervensjonen ble i 2007 gjennomført bl.a. i Akershus, og intervensjonsgruppen er valgt derfra. Kontrollgruppen ble valgt ut blant matchede skoler i Vestfold, som fikk intervensjonen først senere. Vi viser til tabell 1 , to første linjer og til nærmere opplysninger i (58). Ved t0 var det 710 elever $\mathrm{i}$ intervensjonsgruppen og 194 elever i kontrollgruppen. Ved t1 kom det til ytterligere $170 \mathrm{i}$ intervensjonsgruppen og $618 \mathrm{i}$ kontrollgruppen, jfr. linjen 'inkluderte elever' i tabell 1.

Målinger i både test- og kontrollgruppe direkte etter ble gjennomført i perioden 26.02-30.3.07, ved 6 måneder etter intervensjon i perioden 15.09.-15.10.07, og etter 12 måneder i perioden 25.01-31.03.08.

\section{Datainnsamling}

Data ble samlet inn via spørreskjema, se innhold i dette nedenfor. På hvert av tidspunktene fra t0 til t4 ble utfylling av spørreskjemaene gjennomført i en skoletime, se (58).

Ved t0 ble klasser både $\mathrm{i}$ intervensjonsgruppen og kontrollgruppen randomisert til to undergrupper. Den ene fikk spørreskjema like før intervensjonstidspunktet (t0) og umiddelbart etterpå (t1), mens den andre gruppen ikke fikk spørreskjema før intervensjonstidspunktet. Deretter har alle gruppene fått spørreskjema etter 6, 12 og 24 måneder. Det vises til figur 1 og (58).

\section{Sporsmål}

For problemstillingene i denne artikkelen brukte vi følgende spørsmål i spørreskjemaet (for andre spørsmål, se (58)):

'Kjennskap til andres problem': Vet du om venner eller noen i klassen som har psykiske problemer? (Svaralternativer: Nei / én / flere).
'Antatt håndtering av andres eventuelle problem': Hvis du fikk inntrykk av at en venn eller klassekamerat hadde psykiske problemer, hva ville du da gjøre? (Ingenting / snakke med vedkommende / snakke med lærer / rådgiver / helsesøster / familie / hjelpeinstans / søke på internett).

'Antatt håndtering hvis problem selv': Tenk deg at du en måned eller to hadde følt deg nedfor, hatt lite overskudd, ikke orket å gjøre skolearbeidet og hatt lite glede av å være sammen med andre. Hva tror du at du ville ha gjort med problemet? (Håpe at det skulle gå over av seg selv / snakke med psykolog / lærer / skolehelsetjenesten / familie / venn eller kjæreste / fastlege eller annen lege).

'Kontakt med spesialisthelsetjenesten': Har du vært eller er du i kontakt med (barne- og ungdomspsykiatrisk poliklinikk / psykiatrisk ungdomsteam / psykiatrisk akutt-team). Svaralternativer: Ja eller nei.

Selvrapporteringsskjema fra SDQ-Nor (38-39), som inneholder 25 ulike påstander om de siste 6 månedene. Spørreskjemaet er en screening av den psykiske helse gjennom egenrapportering og er utviklet i England av Robert Goodman. Måleinstrumentets psykometriske egenskaper har vært gjenstand for studier både i forhold til andre undersøkelser om nivå av psykiske problemer og i forhold til kliniske vurderinger slik som CBCL (38-49).

Spørreskjemaets 25 påstander kan besvares med "Stemmer ikke", "Stemmer delvis" eller "Stemmer helt". Påstandene skåres med 0,1 og 2 og danner én totalskåre (bestående av 20 ledd, skåring 0-40) og fem delskårer som omhandler emosjonelle problemer, atferdsvansker, oppmerksomhetsvansker/hyperaktivitet, problemer med jevnaldrende og prososial atferd. De fire første delskårene går fra $0-10$ og danner til sammen totalskåren, mens den femte delskåren omhandler atferd for å hjelpe eller ta vare på andre og skåres 0-10.

For å danne et mer dekkende bilde av problemene har vi inkludert innvirkningsskåren i spørreskjemaet (bestående av 5 ledd, skåring 0-10). Den omfatter respondentens opplevelse av problemenes innvirkning på livssituasjon. Høyere gjennomsnittsskåre betyr i alle skalaene dårligere psykisk helse. Skåringen danner grunnlag for en gruppering der vi deler utvalget inn $\mathrm{i}$ "Normalskåre", "Gråsone" (dvs. de vi klassifiserer som å ha psykiske problemer uten å være behandlingstrengende) og "Avvikende" (dvs. de som har psykiske problemer og er behandlingstrengende). Cut-off i de enkelte skalaene er gjort $i$ henhold til standardene som er satt opp av Robert Goodman (38). 
Vi benytter $S D Q$-Nor totalskåre, delskalaen Problemer med jevnaldrende, og Angstsymptomer, som består av 5 ledd hentet fra TOPP-studien (50). Eksempel: Jeg er engstelig i sosiale situasjoner fordi jeg er redd for andre mennesker. Skåre $0-10$. Vi benytter $S D Q$ Nor totalskåre, Problemer med jevnaldrende, Emosjonelle vansker og Innvirkningsskåren.

Innvirkningsskåren i SDQ-Nor omfatter:

Samlet egenvurdering i SDQ-Nor: Synes du at du har vansker med følelser, konsentrasjon, oppførsel eller å komme overens med andre? (Nei / ja, små vansker / ja, tydelige vansker / ja, alvorlige vansker.)

'Innvirkning generelt': Forstyrrer eller plager vanskene deg? (Nei / bare litt / en god del / mye), og

'Spesifikk innvirkning': Virker disse vanskene inn på livet ditt: i hjem, familie? i forhold til venner? i læring på skolen? i fritidsaktiviteter? (Nei / bare litt / en god del / mye).

Elever som ved den samlede egenvurderingen i SDQ-Nor svarte at de hadde vansker (små eller store), ble også bedt om å svare på følgende:

'Hjelp fra andre': Har noen uoppfordret tatt opp vanskelighetene dine med deg? (Klassekamerater / andre venner / lærer / helsesøster / nei, ingen av disse).

'Faktisk håndtering av eget problem': Hva har du selv gjort med problemet? (Samme svaralternativer som ved "antatt håndtering hvis problem selv").

I tillegg bruker vi svar på spørsmål i spørreskjemaet om personlige kjennetegn (kjønn, alder, familiebakgrunn $\mathrm{mm}$ ).

\section{Spesifikke hypoteser}

Vi antar at det på tidspunkt $\mathrm{t} 1$, dvs. kort tid etter intervensjonen, kan være effekter på følgende variable: Kjennskap til andres problem, antatt håndtering $\mathrm{av}$ andres eventuelle problem og antatt håndtering av eget eventuelt problem.

På tidspunkt t2 (6 måneder) og t3 (12 måneder) kan det - blant de som rapporterer om problemer selv på SDQ-Nor - tenkes å være effekter på følgende variable: Hjelp fra andre, faktisk selvhjelp og kontakt med hjelpeapparatet.

På tidspunkt t3 kan det tenkes å være effekter på følgende variable: SDQ-Nor-skalaer, angstsymptomer og innvirkningsskåren i SDQ-Nor.

\section{Databehandling}

På de to spørsmålene om håndtering av andres og eget problem har vi i samråd med professor i psykologi Arne Holte, professor i psykiatri Odd Steffen Dalgard og forskningssjef ved divisjon for psykisk helse ved Folkehelseinstituttet, dr. psychol. Kristian Tambs kommet frem til 'beste svar', dvs. hva som er mest ønsket atferd. For håndtering av andres problem var dette svaralternativ 2, "Snakke med vedkommende og foreslå at vi skal gå å søke hjelp", eller svaralternativ 5, "Snakke med helsesøster". For håndtering av eget problem var det flere mulige 'beste svar', nemlig
"Snakket med lærer", "Tatt kontakt med skolehelsetjenesten", "Snakket med noen i familien", "Snakket med en venn eller kjæresten" eller "Tatt kontakt med fastlegen eller annen lege".

Hver SDQ-Nor skala ble delt i normalsone, gråsone (plaget, men ikke behandlingstrengende) og avvikssone (plaget og behandlingstrengende) etter gjeldende retningslinjer for instrumentet (38).

Innvirkning generelt og spesielt er slått sammen til én indeks. Innvirkningsskåren består av 5 ledd, med svaralternativene "ikke i det hele tatt", "bare litt", "en god del" og "mye", hver påstand skåres henholdsvis 0 , 0, 1, 2 (skåring 0-10).

$\mathrm{Vi}$ beregner prosentvise fordelinger $\mathrm{i}$ intervensjonsog kontrollgruppen på ulike tidspunkter på de ulike variablene. På SDQ skalaer beregner vi dessuten gjennomsnittskårer i de to gruppene.

I analysene av det foreliggende datamaterialet har vi benyttet SPSS 14.0. For SDQ-Nor har vi benyttet nedlastet syntaks for tolkning, oppsett og analyser $\mathrm{i}$ henhold til internasjonale standarder (38).

$\mathrm{Vi}$ har gjort t-tester for signifikans på gjennomsnitt ved enkeltspørsmål og indekser, og deretter på samme måte benyttet General Linear Modell for å teste endringer over de to måletidspunktene, uten at dette har gitt oss en vesentlig merinformasjon annen enn den som her er presentert. I tabellene er signifikante funn merket med én, to eller tre stjerner $(*)$ for henholdsvis $\mathrm{p}<0,05, \mathrm{p}<0,01$ og $\mathrm{p}<0,001$.

Effektstørrelser er angitt både i absolutte tall og som forskjeller mellom gjennomsnitt delt på standardavviket i utvalgene, (Cohens d, jfr. 51,52). Vurderingene av effekter er i henhold til de generelle internasjonale retningslinjer, der 0,2 defineres som en markant men liten effekt, 0,5 som middels effekt og 0,8 som en stor effekt (51-53).

\section{Frafall og kjennetegn ved respondentene}

Blant de inkluderte skjedde det en del frafall. I intervensjonsgruppen var ca halvparten av elevene ved Strømmen videregående skole, som er en yrkesfaglig skole, fraværende ved $\mathrm{t} 0 \mathrm{og} \mathrm{t} 1$ fordi de var ute i praksis. Disse deltok seinere på $\mathrm{t} 2 \mathrm{og} \mathrm{t} 3$. På tidspunkt $\mathrm{t} 2$ fikk noen klasser ved Thor Heyerdahl videregående skole (i kontrollgruppen) ikke fylt ut spørreskjemaet innen oppsatt tidsfrist. Ved $\mathrm{t} 3$ var det samme tilfellet ved Stabekk videregående skole (i intervensjonsgruppen). Ved alle skolene var i tillegg en del innleverte skjemaer utilfredsstillende utfylt. Skjemaer hvor opplysning om elevens kjønn manglet, eller hvor minst halvparten av alle enkeltspørsmål i skjemaet var ubesvart, ble ekskludert fra analysene.

Frafall og deltakelse er oppsummert i tabell 1. Det framgår at responsraten for intervensjonsgruppen alt $\mathrm{i}$ alt var $89 \%$ ved t 2 og $74,3 \%$ t3. For kontrollgruppen var responsratene henholdsvis $71,4 \%$ og $70,6 \%$.

Tabell 2 viser personlige kjennetegn i intervensjonsog kontrollgruppe ved t2. Det er ikke vesentlige for- 
Tabell 1. Antall elever i populasjoner og utvalg og antall svar på ulike tidspunkter.

\begin{tabular}{l|rrrr|rrrr}
\hline & \multicolumn{4}{|c|}{ Akershus } & \multicolumn{4}{c}{ Vestfold } \\
\cline { 2 - 9 } & $\mathrm{t} 0$ & $\mathrm{t} 1$ & $\mathrm{t} 2$ & $\mathrm{t} 3$ & $\mathrm{t} 0$ & $\mathrm{t} 1$ & $\mathrm{t} 2$ & $\mathrm{t} 3$ \\
\hline Antall elever i første klasse $\mathrm{i}$ & & & & & & & & \\
videregående skoler & 7731 & & & & 3464 & & \\
Trukket ut til evalueringsprosjektet & 730 & 943 & & & 206 & 963 & \\
Fylte ikke kriteriene for deltakelse & 20 & 63 & 0 & & 12 & 152 & 0 & \\
Inkluderte elever & 710 & 880 & 880 & 880 & 194 & 811 & 811 & 811 \\
Frafall & 143 & 230 & 97 & 226 & 46 & 93 & 232 & 238 \\
Brukbare besvarelser & 567 & 650 & 783 & 654 & 148 & 718 & 579 & 573 \\
Responsrate i \% & 79,9 & 73,9 & 89 & 74,3 & 76,3 & 88,5 & 71,4 & 70,6 \\
\hline
\end{tabular}

Tabell 2. Personlige kjennetegn ved t2.

\begin{tabular}{|c|c|c|}
\hline \multirow[b]{2}{*}{ Gjennomsnittlig $\mathrm{N}$ for alle variabler (total $\mathrm{N}$ ) } & \multirow{2}{*}{$\begin{array}{c}\text { Intervensjon } \\
\mathrm{N}=729(783)\end{array}$} & \multirow{2}{*}{$\begin{array}{c}\text { Kontroll } \\
\mathrm{N}=516(579)\end{array}$} \\
\hline & & \\
\hline Menn & $52,2 \%$ & $54,4 \%$ \\
\hline Kvinner & $47,8 \%$ & $45,6 \%$ \\
\hline Alder (i år) & 17,15 & 17,14 \\
\hline Inntektsgivende arbeid ved siden av skole & $50,8 \%$ & $58,1 \%$ \\
\hline \multicolumn{3}{|l|}{ Bosituasjon } \\
\hline Bor sammen med både mamma og pappa & $64,3 \%$ & $61,5 \%$ \\
\hline Bor sammen med kun en av foreldrene & $16,2 \%$ & $15,6 \%$ \\
\hline Bor sammen med en av foreldrene med ny samboer & $10,5 \%$ & $9,2 \%$ \\
\hline Bor i fosterhjem & $0,9 \%$ & $1,9 \%$ \\
\hline \multicolumn{3}{|l|}{ Total inntekt for husstanden } \\
\hline $0-400^{\prime} \mathrm{NOK}$ & $13,3 \%$ & $15,1 \%$ \\
\hline $400-800^{\prime} \mathrm{NOK}$ & $24,8 \%$ & $32,8 \%$ \\
\hline $800^{\prime}$ NOK og mer & $28,2 \%$ & $22,8 \%$ \\
\hline Vet ikke & $33,8 \%$ & $29,4 \%$ \\
\hline Gjennomsnittlig inntekt & $686^{\prime}$ & $623^{\prime}$ \\
\hline \multicolumn{3}{|l|}{ Utdanningsnivå for mor } \\
\hline Grunnskole & $13,8 \%$ & $10,7 \%$ \\
\hline Videregående skole & $28,4 \%$ & $37,4 \%$ \\
\hline Høyskole/Universitet mindre enn 4 år & $29,4 \%$ & $28,8 \%$ \\
\hline Høyskole/Universitet mer enn 4 år & $28,2 \%$ & $22,9 \%$ \\
\hline \multicolumn{3}{|l|}{ Utdanningsnivå for far } \\
\hline Grunnskole & $14,6 \%$ & $12,1 \%$ \\
\hline Videregående skole & $27,7 \%$ & $39,0 \%$ \\
\hline Høyskole/Universitet mindre enn 4 år & $21,8 \%$ & $24,7 \%$ \\
\hline Høyskole/Universitet mer enn 4 år & $35,5 \%$ & $24,2 \%$ \\
\hline \multicolumn{3}{|l|}{ Fødeland } \\
\hline Norge & $92,7 \%$ & $93,5 \%$ \\
\hline Annet land & $7,3 \%$ & $6,3 \%$ \\
\hline \multicolumn{3}{|l|}{ Fødeland, mor } \\
\hline Norge & $87,2 \%$ & $90,8 \%$ \\
\hline Annet land & $12,8 \%$ & $9,2 \%$ \\
\hline \multicolumn{3}{|l|}{ Fødeland, far } \\
\hline Norge & $85,9 \%$ & $92,6 \%$ \\
\hline Annet land & $14,1 \%$ & $7,4 \%$ \\
\hline
\end{tabular}

skjeller når det gjelder kjønnssammensetning, alder, inntektsgivende arbeid eller bosituasjon. Det er heller ikke vesentlige forskjeller når det gjelder husstandsinntekt, men disse tallene er mer usikre ettersom 33,8 og 29,4\% svarer "vet ikke". Det er noe høyere andel i intervensjonsgruppen av foreldre med mer enn fire års universitetsutdanning og av foreldre født et annet sted enn i Norge (se kommentar i diskusjonsdelen).

\section{ReSUltater}

Mulige virkninger på tidspunkt t1 (rett etter intervensjonen) er belyst i tabell 3. I både intervensjons- og kontrollgruppen var det flere ved $\mathrm{t} 1$ som sa de visste om andre som har psykiske problemer enn det var ved t0 (rett før intervensjon). Nedgangen i prosentandelen 'uvitende om andre med problemer' er større i kon- 
Tabell 3. Prosentfordelinger av gruppe 1 (intervensjon) og gruppe 2 (kontroll) rett før og rett etter intervensjonen på variablene 'kjennskap til andres problem', 'antatt håndtering av andres eventuelle problem' og 'antatt håndtering av eget problem'.

\begin{tabular}{|c|c|c|c|c|c|c|}
\hline \multirow[b]{2}{*}{ Spørsmål /variabler } & \multicolumn{2}{|c|}{ Intervensjonsgruppe 1} & \multicolumn{2}{|c|}{ Kontrollgruppe 2} & \multicolumn{2}{|c|}{ Endring } \\
\hline & Før & Etter & Før & Etter & Gruppe 1 & Gruppe 2 \\
\hline \multicolumn{7}{|l|}{ Kjennskap til andres problem } \\
\hline 1. Nei, ingen & 50,5 & 43,1 & 54,9 & 42,2 & $-7,4$ & $-12,7$ \\
\hline 2. Ja, én & 28,1 & 31,2 & 26,1 & 38,3 & 3,1 & 12,2 \\
\hline 3. Ja, flere & 21,4 & 25,7 & 19,0 & 19,5 & 4,3 & 0,5 \\
\hline $\mathrm{N}$ & 555 & 490 & 142 & 128 & & \\
\hline \multicolumn{7}{|l|}{ Antatt håndtering av andres eventuelle problem } \\
\hline 1. Ville ikke gjort noen ting & 6,9 & 9,3 & 14,5 & 11,8 & 2,4 & $-2,7$ \\
\hline 2. Snakket med og/eller tatt kontakt med familie & 54,5 & 49,4 & 53 & 53,9 & $-5,1$ & 0,9 \\
\hline 3. Tatt kontakt med en profesjonell & 38,6 & 41,3 & 32,5 & 34,3 & 2,7 & 1,8 \\
\hline $\mathrm{N}$ & 454 & 427 & 117 & 102 & & \\
\hline \multicolumn{7}{|l|}{ Antatt håndtering hvis problem selv } \\
\hline 1. Ingen ting & 20,3 & 15,1 & 18,9 & 26,4 & $-5,2$ & $7,5 * *$ \\
\hline 2. Tatt kontakt med venner eller familie & 51,3 & 60,0 & 48,8 & 48,8 & 8,7 & 0,0 \\
\hline 3. Tatt kontakt med en profesjonell & 28,4 & 24,9 & 32,3 & 24,8 & $-3,5$ & $-7,5$ \\
\hline 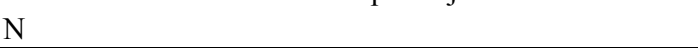 & 493 & 485 & 127 & 125 & & \\
\hline
\end{tabular}

trollgruppen enn $\mathrm{i}$ intervensjonsgruppen (12,7 vs. 7,4 prosentpoeng), men forskjellen er ikke signifikant. Det er ingen klare endringer i svarfordelinger på 'antatt håndtering av andres eventuelle problem', verken i intervensjons- eller kontrollgruppen. Derimot er det $\mathrm{i}$ intervensjonsgruppen en nedgang på 5,2 prosentpoeng $\mathrm{i}$ andelen som sier de ikke ville ha foretatt seg noe $\mathrm{i}$ tilfelle eget problem, mens det på samme svarkategori var en oppgang på 7,5 prosentpoeng i kontrollgruppen. Forskjellen i endring har en p-verdi på 0,007.

Tabell 4 dekker tidspunktene $\mathrm{t} 1$, $\mathrm{t} 2$ og t3. På hvert av disse tidspunktene omfatter tabellen bare de elevene som på vedkommende tidspunkt rapporterte at de i mer enn 1 måned hadde hatt vansker med følelser, konsentrasjon, oppførsel eller med å komme overens med andre mennesker (samlet egenvurdering i SDQ-Nor). Tabellen viser fordelingene av personer i hhv gruppe $1+3$ (intervensjon) og gruppe $2+4$ (kontroll) på hvert av de tre tidspunktene på variablene 'hjelp fra andre', 'faktisk håndtering av eget problem' og 'kontakt med spesialisthelsetjenesten'. Det er i intervensjonsgruppen svært små forandringer fra $\mathrm{t} 1$ til $\mathrm{t} 2 \mathrm{og} \mathrm{t} 3$ på alle variablene i tabellen. Det er gunstigere utvikling i intervensjonsgruppen enn kontrollgruppen på variabelen 'faktisk håndtering av eget problem' men forskjellen er ikke signifikant.

Tabell 5 viser gjennomsnittsskårer, effekt og signifikans på variablene "totalskåre i SDQ-Nor", "problemer med jevnaldrende" og "angst" på tidspunktene t1 og t3. For å gjøre målinger av signifikansnivået er vi avhengig av at respondentene har svart på begge tidspunkt og $\mathrm{N}$ blir derfor en del lavere enn den totale $\mathrm{N}$ på hvert av tidspunktene. Det er en svak nedgang i totalskåren i intervensjonsgruppen og noe økning i kontrollgruppen. Forskjellen er signifikant på 0,01 nivå med en effektstørrelse på $\mathrm{d}=0,15$. I delskåren "problemer med jevnaldrende" finner vi samme mønsteret. Her er effektstørrelsen $\mathrm{d}=0,31$ med en $\mathrm{p}$-verdi på
0,005. For angst går også skåren ned i intervensjonsgruppen og opp i kontrollgruppen. Forskjellen er statistisk signifikant, med p-verdi $<0,001$, og effektstørrelse på $\mathrm{d}=0,37$. Intraklassekorrelasjonen ved SDQ-totalskåren er i GLM målt til 0,11 ved t1 og 0,06 ved $\mathrm{t} 2$ og t3. Funnene følger en klar simplex-struktur. Det vil si at $\mathrm{t} 1$ mot $\mathrm{t} 2$ og $\mathrm{t} 2$ mot $\mathrm{t} 3$ korrelerer høyere med hverandre enn $\mathrm{t} 1$ mot $\mathrm{t} 3$. At $\mathrm{t} 2$ - $\mathrm{t} 3$ korrelerer høyere enn $\mathrm{t} 1-\mathrm{t} 2$, tyder på at det som måles konsolideres med alderen.

Tabell 6 viser fordelingene av gruppe $1+3$ (intervensjon) og gruppe $2+4$ (kontroll) på tidspunkt $\mathrm{t} 1 \mathrm{og} \mathrm{t} 3$ på normal, grå og avvikende sone på fire skalaer $\mathrm{i}$ SDQ-Nor.

På totalskåre i SDQ-Nor er det svak oppgang i andelene $\mathrm{i}$ gråsone og avvikende sone for både intervensjons- og kontrollgruppen, men ingen signifikant forskjell mellom disse (differansen er 1,1\%).

På 'emosjonelle vansker' er det i intervensjonsgruppen noe nedgang $\mathrm{i}$ andelen i normalsonen, mens det er svært liten endring i kontrollgruppen (differansen er på $3,1 \%)$.

På 'problemer med jevnaldrende' er det i intervensjonsgruppen ingen endring, mens det i kontrollgruppen er en svak økning i gråsone og avvikende sone (differansen er på 3,8\%).

På variabelen "innvirkningskåre" er det i intervensjonsgruppen en større nedgang $i$ andelen $i$ avvikende sone, mens det i kontrollgruppen er forskyvning fra gråsone til avvikende sone. Forskjellen mellom utviklingene $\mathrm{i}$ de to gruppene $\mathrm{i}$ avvikende sone er $13,0 \%$.

\section{DISKUSJON}

På tidspunkt t1 var det $\mathrm{i}$ intervensjonsgruppen en nedgang på 5,2 prosentpoeng $\mathrm{i}$ andelen som sa de ikke ville ha foretatt seg noe i tilfelle eget problem, mens det på samme svarkategori var en oppgang på 7,5 pro- 
Tabell 4. Hjelp fra andre, faktisk selvhjelp og kontakt med psykiatrisk hjelpeapparat på tidspunktene t1-t3 blant elever som rapporterte om vansker. Prosent.

\begin{tabular}{|c|c|c|c|c|c|c|}
\hline \multirow[b]{2}{*}{ Spørsmål } & \multicolumn{3}{|c|}{ Intervensjonsgruppe $1+3$} & \multicolumn{3}{|c|}{ Kontrollgruppe $2+4$} \\
\hline & $\mathrm{t} 1$, rett etter & $\mathrm{t} 2,6 \mathrm{mnd}$ & $\mathrm{t} 3,12 \mathrm{mnd}$ & $\mathrm{t} 1$, rett etter & $\mathrm{t} 2,6 \mathrm{mnd}$ & $\mathrm{t} 3,12 \mathrm{mnd}$ \\
\hline \multicolumn{7}{|l|}{ Uoppfordret hjelp fra andre } \\
\hline 1. Ingen & 65,4 & 64,0 & 64,4 & 53,3 & 62,5 & 58,9 \\
\hline 2. Venner og kjente & 17,7 & 15,6 & 17,6 & 24,4 & 21,4 & 22,9 \\
\hline 3. Lærer eller helsesøster & 16,9 & 20,4 & 18,0 & 22,2 & 15,8 & 18,2 \\
\hline 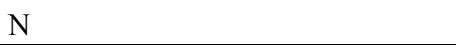 & 231 & 250 & 261 & 45 & 253 & 192 \\
\hline \multicolumn{7}{|l|}{ Faktisk håndtering av eget problem } \\
\hline 1. Ingen & 34,2 & 34,7 & 32,5 & 30,3 & 34,5 & 36,9 \\
\hline 2. Venner og kjente & 46,8 & 42,6 & 41,4 & 51,5 & 41,9 & 34,2 \\
\hline 3. Profesjonelt hjelpeapparat & 18,9 & 22,7 & 26,0 & 18,2 & 23,6 & 28,8 \\
\hline 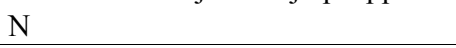 & 190 & 216 & 169 & 33 & 203 & 111 \\
\hline \multicolumn{7}{|l|}{ Nåværende eller tidl kontakt med BUP } \\
\hline 1. Nei & 81,3 & 80,8 & 79,6 & 79,9 & 77,3 & 80,3 \\
\hline 2. Ja & 18,7 & 19,2 & 20,4 & 20,1 & 22,7 & 19,7 \\
\hline $\mathrm{N}$ & 208 & 214 & 181 & 198 & 154 & 117 \\
\hline \multicolumn{7}{|l|}{ Nåværende eller tidl kontakt med PUT } \\
\hline 1. Nei & 94,7 & 96,7 & 93,9 & 98,5 & 94,8 & 92,3 \\
\hline 2. Ja & 5,3 & 3,3 & 6,1 & 1,5 & 5,2 & 7,7 \\
\hline $\mathrm{N}$ & 206 & 213 & 181 & 197 & 154 & 117 \\
\hline \multicolumn{7}{|l|}{ Kontakt med Psyk Akutteam } \\
\hline 1. Nei & 96,6 & 97,7 & 93,9 & 96,9 & 94,8 & 97,4 \\
\hline 2. Ja & 3,4 & 2,3 & 6,1 & 3,1 & 5,2 & 2,6 \\
\hline $\mathrm{N}$ & 207 & 213 & 180 & 196 & 154 & 117 \\
\hline
\end{tabular}

Tabell 5. Gjennomsnittsskårer på SDQ-Nor totalskåre, delskala for problemer med jevnaldrende og angst på tidspunkt $\mathrm{t} 1 \mathrm{og} \mathrm{t} 3$ (kun de som har fylt ut på begge tidspunkter).

\begin{tabular}{|c|c|c|c|c|c|c|}
\hline & $\begin{array}{l}\text { Intervensjons- } \\
\text { gruppe } 1+3\end{array}$ & SD & $\mathrm{N}$ & $\begin{array}{l}\text { Kontroll- } \\
\text { gruppe } 2+4\end{array}$ & SD & $\mathrm{N}$ \\
\hline SDQ-Nor totalskåre $0-40$ & & & & & & \\
\hline Rett etter intervensjonen & 9,22 & 5,8 & 276 & 8,88 & 5,1 & 249 \\
\hline Etter $12 \mathrm{mnd}$ & 8,90 & 5,4 & 276 & 10,08 & 6,2 & 249 \\
\hline Forskjell i endring i prosent av skalaens lengde & \multicolumn{6}{|c|}{$3,80 \%$} \\
\hline Effekt ved Cohens d & \multicolumn{6}{|c|}{0,15} \\
\hline Signifikansnivå ved t-test & \multicolumn{6}{|c|}{, 007} \\
\hline \multicolumn{7}{|l|}{ Problemer med jevnaldrende $0-10$} \\
\hline Rett etter intervensjonen & 1,54 & 1,7 & 276 & 1,34 & 1,6 & 249 \\
\hline Etter 12 mnd & 1,34 & 1,6 & 276 & 1,63 & 1,9 & 249 \\
\hline Forskjell i endring i prosent av skalaens lengde & \multicolumn{6}{|c|}{$4,90 \%$} \\
\hline Effekt ved Cohens d & \multicolumn{6}{|c|}{0,31} \\
\hline Signifikansnivå ved t-test & \multicolumn{6}{|c|}{, 009} \\
\hline Angstskala $0-10$ & & & & & & \\
\hline Rett etter intervensjonen & 1,27 & 1,8 & 269 & 1,01 & 1,5 & 240 \\
\hline Etter 12 mnd & 0,94 & 1,5 & 269 & 1,36 & 2,0 & 240 \\
\hline Forskjell i endring i prosent av skalaens lengde & \multicolumn{6}{|c|}{$6,80 \%$} \\
\hline Effekt ved Cohens d & \multicolumn{6}{|c|}{0,37} \\
\hline Signifikansnivå ved t-test & \multicolumn{6}{|c|}{001} \\
\hline
\end{tabular}

sentpoeng i kontrollgruppen. Dette er en indikasjon på at intervensjonen kan ha ført til en ønsket holdningsendring når det gjelder hjelpsøking. Funnet er signifikant, men effekten er ikke veldig sterk. Det er imidlertid vanskelig å si i hvilken grad personer i intervensjonsgruppen svarer slik de gjennom intervensjonen har forstått at de "bør" svare snarere enn å gjøre en realistisk vurdering.
Svarene på spørsmål om faktisk hjelpsøking blant de som etter 6 og 12 måneder rapporterte om vansker med følelser, konsentrasjon, oppførsel eller det å komme overens med andre viser noe mer positiv utvikling for intervensjonsgruppen, men er ikke statistisk signifikant. På variabelen 'kontakt med psykiatrisk ungdomsteam' økte andelen i kontrollgruppen med slik kontakt fra 1,5 til 7,7 prosent fra $\mathrm{t} 1 \mathrm{til} \mathrm{t} 3$, mens den økte bare 
Tabell 6. Fordeling av svar på normalsone, gråsone og avvikende sone for SDQ-Nor variablene "totalskåre", "emosjonelle vansker" og "problemer med jevnaldrende" og "innvirkning". Prosent.

\begin{tabular}{lcccccccc}
\hline Indekser & \multicolumn{3}{c}{ Intervensjonsgruppe 1+3 } & \multicolumn{5}{c}{ Kontrollgruppe 2+ } \\
\hline & Normal & Gråsone & Avvikende & Normal & Gråsone & Avvikende \\
SDQ-Nor, totalskåre & $(0-15)$ & $(16-19)$ & $(20-40)$ & $N$ & $(0-15)$ & $(16-19)$ & $(20-40)$ & $N$ \\
\hline Rett etter intervensjonen & 85,6 & 8,1 & 6,3 & 589 & 86,8 & 8,2 & 5,0 & 662 \\
Etter 12 mnd & 83,1 & 9,8 & 7,1 & 496 & 83,0 & 9,7 & 7,3 & 401 \\
\hline & Normal & Gråsone & Avvikende & Normal & Gråsone & Avvikende \\
SDQ-Nor, emosjonelle vansker & $(0-5)$ & $(6)$ & $(7-10)$ & $N$ & $(0-5)$ & $(6)$ & $(7-10)$ & $N$ \\
Rett etter intervensjonen & 88,1 & 5,2 & 6,7 & 629 & 87,7 & 4,0 & 8,3 & 708 \\
Etter 12 mnd & 84,7 & 6,5 & 8,8 & 537 & 87,4 & 4,9 & 7,7 & 426 \\
\hline & Normal & Gråsone & Avvikende & Normal & Gråsone & Avvikende \\
SDQ-Nor, problemer med jevnaldrende & $(0-3)$ & $(4-5)$ & $(6-10)$ & $N$ & $(0-3)$ & $(4-5)$ & $(6-10)$ & $N$ \\
Rett etter intervensjonen & 84,1 & 12,4 & 3,5 & 627 & 90,0 & 7,4 & 2,6 & 698 \\
Etter 12 mnd & 83,3 & 13,0 & 3,7 & 538 & 85,4 & 9,2 & 5,4 & 425 \\
\hline & Normal & Gråsone & Avvikende & Normal & Gråsone & Avvikende \\
SDQ-Nor, innvirkningsskåre & $(0)$ & $(1)$ & $(2-10)$ & $N$ & $(0)$ & $(1)$ & $(2-10)$ & $N$ \\
Rett etter intervensjonen & 39,5 & 13,2 & 47,3 & 220 & 40,5 & 19,5 & 40,0 & 215 \\
Etter 12 mnd & 44,8 & 15,5 & 39,7 & 181 & 41,2 & 13,4 & 45,4 & 119 \\
\hline
\end{tabular}

fra 5,3 til 6,1 prosent i intervensjonsgruppen. Økningen er i overensstemmelse med tall fra andre undersøkelser (1-3) og tyder på at det er en normalutvikling i populasjonen ettersom respondentene $\mathrm{i}$ all hovedsak er blitt 18 år ved t3.

Fra tidspunkt t 1 til t3 finner vi på den annen side signifikant gunstigere utvikling i intervensjonsgruppen enn i kontrollgruppen mht totalskåre på SDQ-Nor, på skåre for "problemer med jevnaldrende" og angst. Effektstørrelsen for totalskåren er på $\mathrm{d}=0,15$, for problemer med jevnaldrende $\mathrm{d}=0,31$ og for angst $\mathrm{d}=0,37$. Selv om dette er små effekter, er de bemerkelsesverdige av flere grunner. VIP fokuserer først og fremst på kunnskapsoppbygning og dialog og er bare en liten brikke i det store spillet som bestemmer om og i hvilken grad skoleelever har psykiske plager og eventuelt søker hjelp for disse. Vi har heller ikke funnet nevneverdige effekter på endring av hjelpsøking til det profesjonelle hjelpeapparatet. Dette kan henge sammen med at en stor andel av respondentene i intervensjonsgruppen oppgir venner og familie som primærpart å henvende seg til ved problemer. Funnet av effekter på symptomnivå etter 12 måneder er likevel slående. En mulig forklaring kan være at VIP-intervensjonen kanskje fører til mer hensynsfull og/eller inkluderende atferd overfor elever som synes å ha problemer, uten at dette fanges opp av spørsmålene i denne undersøkelsen. Dette vil i så fall stemme med at den relativt sett sterkeste effekten er på variabelen angst.

Elever ble rekruttert inn i studien klassevis. Slik "clustring" gir rom for tilfeldige utslag som de foretatte t-testene ikke fullt ut fanger opp, og p-verdiene i tabell 5 kan derfor gi et noe overdrevet bilde av signifikansnivået for det observerte effektene. På den annen side ligger de beregnede verdiene langt under den konvensjonelle grensen på 0,05 .
Det er interessant å sammenlikne effektene av VIPprogrammet med effekter av andre forebyggende tiltak av liknende karakter. Vi kjenner imidlertid ikke til direkte sammenliknbare undersøkelser i Norge. I intervensjon "Effektevaluering av opplæringsprogrammene Hva er det med Monica?, STEP - ungdom møter ungdom og Venn1.no" (54) og "Alle har en psykisk helse: Effektevaluering av en tredelt undervisningspakke for ungdomsskoletrinnet" (55-57), ligger effektstørrelsene mellom 0,01 og 0,3 , men disse har kun målinger på endring av kunnskap, og store metodiske svakheter.

I "Det norske universelle forebyggende programmet for sosial angst" (31) fant man signifikante reduksjoner av angst. Programmet fokuserer imidlertid kun på reduksjon av angst, går over en lengre tidsperiode og har en mer altomfattende karakter. Det er betegnet som et universelt program, men har sekundærforebyggende innslag. Funnene peker likevel i samme retning som det vi har funnet.

En annen sammenlikningsmulighet er Olweusprogrammet mot mobbing. Her finnes det mange studier, men de to studiene som presenterer de beste effektendringene er bygget på kvasieksperimentell metode med kohort design. I evalueringene av programmet blir effektene presentert i relative prosentsatser på nedgang i mobbing og mobbere og ligger mellom 33 og 47\% (32). Endringer i absolutte tall er mellom 3,1 og 6,5\% med OR mellom 1,43 og 2,89 i positiv retning (23), dvs. omtrent som endringen vi finner på psykisk helse indikatorene.

I internasjonale undersøkelser, herunder både longitudinelle studier $(10,12)$ og kunnskapsoppsummeringer om universelle forebyggende intervensjoner innen angst, depresjon og psykisk helse (9-27) varierer effektstørrelsene (Cohens d) fra -0,62 til 1,51. I de aktuelle sammenliknbare studiene er imidlertid variasjonen $\mathrm{i}$ 
effektstørrelsene langt mindre og ligger mellom 0,26 til $0,57(9,11,12,17,19,20,22,23,26,27)$.

Det er et begrenset antall studier som har målinger etter 6 og 12 måneder (9-27). De studiene som har longitudinelle design har gjort funn som er i tråd med det vi har funnet. Det er imidlertid knyttet en del usikkerhet til mange av disse resultatene på grunn av design og frafall, men også fordi effekten i en del av undersøkelsene er en artefakt av programmer som var målrettet for å redusere f.eks. angst hos angstpasienter $(9,13,24)$.

Til slutt nevner vi at undersøkelsen har flere mulige feilkilder. Vi har nevnt muligheten av at noen elever, særlig i intervensjonsgruppen, på holdningsspørsmål svarer det de antar at spørsmålsstillerne ønsker at de skal svare. En annen svakhet knytter seg til designet. Det er en styrke at utviklingen $\mathrm{i}$ intervensjonsgruppen sammenliknes med utviklingen i en skole- og klassemessig matchet kontrollgruppe. Men samtidig må det erkjennes at et slikt design kan være mindre godt enn et opplegg der alle elever er randomisert til den ene eller den andre gruppen. Det sistnevnte var ikke praktisk mulig, men det betyr at muligheter for systematiske forskjeller mellom de to gruppene, som kan ha hatt betydning for resultatene, ikke kan utelukkes.

$\mathrm{Vi}$ har tidligere undersøkt konsekvenser av helt manglende utfylling av spørreskjemaet i noen klasser ved enkelte skoler på enkelte tidspunkter. Vi fant at resultater sto seg når vi kontrollerte for dette (58). Frafall i form av utilstrekkelig utfylling av skjema øker fra t1 til t3 i både intervensjons- og kontrollgruppen. Vi har ingen holdepunkter for å anta at dette frafallet skaper systematiske skjevheter ved sammenlikninger mellom gruppene.

Som nevnt var det $\mathrm{i}$ intervensjonsgruppen en høyere andel av foreldre med mer enn fire års universitetsutdanning og av foreldre født et annet sted enn i Norge (se kommentar i diskusjonsdelen). På tidspunkt $\mathrm{t} 1$ fant vi ikke vesentlige forskjeller mellom foreldreutdanningsgrupper mht effekter (58). I bakgrunnsanalyser finner vi heller ikke på tidspunkt $\mathrm{t} 2$ slike subgruppe- forskjeller, og heller ikke hvis vi skiller på foreldres fødested.

\section{KONKLUSJON}

Målet for VIP-programmet er å fremme elevers psykiske helse ved å øke deres kunnskaper om psykisk helse, forbedre deres evne til gjenkjennelse av signaler på psykiske lidelser hos seg selv og andre og å senke terskelen for å hjelpe andre og for selv å søke hjelp. Vi har tidligere funnet at programmet på helt kort sikt har effekter både på generelle kunnskaper om psykisk helse og på kunnskaper om hjelpeapparatet (58).

I denne artikkelen har vi vist at det etter 6 og 12 måneder synes å være en liten effekt på hjelpsøking. Innvirkningen på dagliglivet blant de som faktisk har problemer er positiv (13\% bedre utvikling etter 12 måneder), men ikke statistisk signifikant. Derimot har vi funnet statistisk signifikante gunstige effekter på totalskåren i SDQ-Nor, problemnivå med jevnaldrende og angst etter 12 måneder. Vi finner dette bemerkelsesverdig gitt VIP-intervensjonens moderate omfang og den store sammenhengen som VIP-programmet forekommer i. Effektene er ikke store, men små bidrag til økt kunnskap og bedre mestring gjennom VIPprogrammet kan godt være forsvarlige hvis det oppnås med lave kostnader. En nærmere analyse av programmets kostnader vil således være av interesse. En detaljert kostnadsanalyse går imidlertid utenfor rammen for denne artikkelen.

De funnene vi gjør, peker i retning av at forebyggende informasjon $\mathrm{i}$ skolen kan være et verdifullt supplement til øvrige tiltak for å fremme psykisk helse. Resultatene kan ha implikasjoner for satsing og ressursfordeling for planlegging og tilrettelegging av psykisk helsetjeneste og for læringsaktiviteter i skolen. Det er imidlertid behov for ytterligere analyser med hensyn til langtidseffekter, clustereffekter og identifisering av særlige innsatsområder. Ideelt sett skulle man gjerne se om resultatene av denne studien holder seg i uavhengige seinere studier av det samme.

\section{REFERANSER}

1. Sosial- og helsedepartementet. Faktarapport om årsaker til psykiske plager og lidelser. 2000.

2. Nasjonalt kunnskapssenter for helsetjenesten. Helseprofil for barn og ungdom i Akershus - Ungdomsrapport. 2004; 2: 102-139.

3. Nasjonalt Folkehelseinstitutt. Rapport 2009:1 13-15 åringer fra vanlige familier i Norge - hverdagsliv og psykisk helse. Folkehelseinstituttet, Oslo. 2009; 1. www.fhi.no/eway/default.aspx?pid=233\&trg=MainLeft 5565\&MainArea_5661=5565:0:15,2336:1:0:0:::0:0\&MainLeft_5565=5603:73517::1:5793:1:::0:0.

4. Feldman MA (Ed). Early intervention: The essential readings. Malden: Blackwell Publishing, 2004: 214-235.

5. Kupfer DJ, Frank E, Perel JM. The advantage of early treatment intervention in recurrent depression. Arch Gen Psychiatry 1989; 9: 771-5.

6. Jørgensen P, Larsen TK, Rosenbaum B. Tidlig indsats ved skizofreni - Utvikling og behandling. København, Fadl's Forlag, 2000: 93-104.

7. Aronen ET, Arajärvi T. Effects of early intervention on psychiatric symptoms of young adults in low-risk and high-risk families. Am J Orthopsychiatry 2000; 2: 223-232. 
8. Mentore JL. The effectiveness of early intervention with young children "at risk": a decade in review. Dissertation Abstracts International: Section B: The Sciences and Engineering 2000: 7-B.

9. Durlak J. Primary prevention mental health programs for children and adolescents are effektive. J Mental Health 1998; 5: 463-469.

10. Pinfold V, Toulmin H, Thornicroft G, Huxley P, Farmer P, Graham G. Reducing psychiatric stigma and discrimination: evaluation of educational interventions in UK secondary schools. Brit J Psych 2003; 182: 342-346.

11. Merry SN, McDowell HH, Hetrick SE, Bir JJ, Muller N. Psycological and/or educational interventions for the prevention of depression in children and adolecents. The Cochrane Collaboration. Wiley \& Sons, 2000: 2.

12. Dulak JA, Wells AM. Primary prevention mental health programs for children and adolescents: a metaanalytic review. Am J Community Psychol 1997; 2: 115-152.

13. Cuijpers P, m.fl. Preventing the onset of depressive disorders: a meta-analytic review of psychological interventions. Am J Psych 2008; 165: 1272-1280.

14. Weisz JR, Sandler IN, Durlak JA, Anton BS. Promoting and protecting youth mental health through evidencebased prevention and treatment. Am Psychol 2005; 6: 628-648.

15. Weist MD, Albus KE. Expanded school mental health. Behav Modif 2004; 4: 463-616.

16. Lipsey MW, Wilson DB. The efficacy of psychological, educational and behavioural treatment: Confirmation from meta-analysis. Am Psychol 1993; 48: 1181-1209.

17. Tennant R, Goens C, Barlow J, Day C, Stewart-Brown S. A systematic review of reviews of interventions to promote mental health and prevent mental health problems in children and young people. $J$ Pub Mental Health 2007; 1: 25-32.

18. Gillham, JE, Shatte AJ, Freres DP. Preventing depression: a review of cognitive behavioral and family interventions. Appl Prev Psychol 2000; 9: 63-88.

19. Greeberg MT, m.fl. Enhancing school-based prevention and youth development through coordinated social, emotional, and academic learning. Am Psychol 2003; 58: 466-474.

20. Jané-Llopis E. From evidence to practice: Mental health promotion effectiveness. Int Union for Health Promo and Ed (IUHPE): Promo \& Ed, Supp 1 2005: 21-27.

21. Gladstone TR, Beardslee WR. The prevention of depression in children and adolescents: a review. Can $J$ Psychiatry 2009; 54: 212-21.

22. Van Voorhees BW. School based prevention programme may reduce depressive episodes in adolescents at risk. Evid Based Mental Health 2010; 13: 15.

23. Farrington DP, Ttofi MM. School-based programs to reduce bullying nand victimation. Campb Syst Rev 2009: 6 .

24. Horowitz JL, Garber J. The prevention of depressive symptoms in children and adolescents: a meta-analytic review. J Cons Clin Psychol 2006; 3: 401-415.

25. Neil A, Christensen H. Efficacy and effectiveness of school-based prevention and early intervention programs for anxiety. Clin Psychol Rev 2009; 3: 208-215.

26. Wells J, Barlow J, Stewart-Brown S. A systematic review of universal approaches to promotion in schools. Health Ed 2003; 4: 197-220.

27. Browne G, Gafni A, Roberts J, Byrne C, Majumdar B. Effective/efficient mental health programs for schoolage children: a synthesis of reviews. Soc Sci Med 2004; 58: 1367-84.

28. Stallard P. Mental health preventive in UK classrooms: the Friends anxiety prevention programme. Emo Behav Diff 2010; 1: 23-25.

29. Pössel P, Baldus C, Horn AB, Groen G, Hautzinger M. Influence of general self-efficacy on the effects of a school-based universal primary prevention program of depressive symptoms in adolescents: a randomized and controlled follow-up study. J Child Psychol Psychiatry 2005; 9: 982-994.

30. Henderson C, Thornicroft G. Stigma and discrimination in mental illness: time to change. Lancet 2009; 373: 1928-1930.

31. Aune T, Stiles TC. Universal-based prevention of syndromal and subsyndromal social anxiety: a randomized controlled study. J Consult Clin Psychol 2009; 77: 867-879.

32. Olweus D, Limber SP. Bullying in school: evaluation and disseminiation of the Olweus Bullying Prevention Program. Am J Orthopsych 2010; 1: 124-134.

33. Roland E, Bru E, Midthassel UV, Vaaland GS. The Zero programme against bullying: Effects of the programme in the context of the Norwegian manifesto against bullying. Soc Psychol Educ 2010; 13: 41-55.

34. Ertesvåg SK, Vaaland GS. Prevention and reduction of behavioural problems in school: An evaluation of the Respect program. Educ Psychol 2007; 27: 713-736.

35. Sørlie MA, Ogden T. Immediate impacts of PALS: A school-wide multi-level programme targeting behaviour problems in elementary school. Scand J Educ Res 2007; 51: 471-492.

36. Holsen I, Smith BH, Frey KS. Outcomes of the social competence program Second Step in Norwegian elementary schools. Sch Psychol Int 2008; 29: 71-88. 
37. http://www.vipweb.no.

38. Goodman R, Meltzer H, Bailey V. The Strengths and Difficulties Questionnaire: a pilot study on the validity of the self-report version. Eur Child Adolesc Psych 1998; 7: 125-130. http:/www.sdqinfo.com/.

39. Heyerdahl S. SDQ - Strength and Difficulties Questionnaire: En orientering om et nytt spørreskjema for kartlegging av mental helse hos barn og unge, brukt i UNGHUBRO, OPPHED og TROFINN. Norsk Epidemiologi 2003; 13: 127-135.

40. Obel C m.fl. The strengths and difficulties questionnaire in the nordic contries. Eu Child Ad Psych 2004; 2: 32-39.

41. Goodman R. Psychometric properties of the strengths and difficulties questionnaire. J Am Acad Child Adolesc Psych 2001; 40: 1337-1345.

42. Goodman R, Scott S. Comparing the Strengths and Difficulties Questionnaire and the Child Behavior Checklist: is small beautiful? J Ab Child Psychol 1999; 27: 17-24.

43. Hawes DJ, Dadds MR. Australian data and psychometric properties of the Strengths and Difficulties Questionnaire. Aust N Z J Psychiatry 2004; 38: 644-651.

44. Koskelainen M, Sourander A, Vauras M. Self-reported strengths and difficulties in a community sample of Finnish adolescents. Eu Child and Adolesc Psych 2001; 10: 180-185.

45. Malmberg M, Rydell AM, Smedje H. Validity of the Swedish version of the Strengths and Difficulties Questionnaire (SDQ-Swe). Nordic J Psych 2003; 57: 357-363.

46. Lundh GL, Wångby M, Bjærehed J. Self reported emotional and behavioral problems in Swedish 14 to 15 year old adolescents: A study with the self report version of the Strengths and Difficulties Questionnaire. Scand J Psychol 2009; 49: 523-532.

47. Van Roy B, Grøholt B, Heyerdahl S, Clench-Aas J. Self-reported strengths and difficulties in a large Norwegian population 10-19 years. Age and gender specific results of the extended SDQ-questionnaire. Eu Child Adolesc Psych 2006; 15: 189-198.

48. Rønning JA, Handegaard BH, Sourander A, Mørch WT. The Strengths and Difficulties Self-Report Questionnaire as a screening instrument in Norwegian community samples. Eu Child Adolesc Psych 2004; 13: 73-82.

49. Smedje H, Broman JE, Hetta J, von Knorring AL. Psychometric properties of a Swedish version of the 'Strengths and Difficulties Questionnaire'. Eu Child Adolesc Psych 1999; 8: 63-70.

50. Mathisen KS. 2010. http://www.fhi.no/eway/default.aspx?pid=233\&trg=MainArea_5661\&MainArea_5661= 5565:0:15,4333:1:0:0:::0:0\&MainLeft_5565=5544:61134::1:5569:3:::0:0.

51. Cohen J. Statistical power analysis for the behavioural sciences (2nd edn). Hillsdale, NJ: Erlbaum, 1988.

52. Durlak JA. How to select, calculate, and interpret effect sizes. J Pediatr Psychol 2009; 9: 917-928.

53. Pedhazur EJ, Schmelkin LP. Measurement, Design, and Analysis. Hillsdale, NJ: Erlbaum, 1991.

54. Andersson HW, Kaspersen SL, Bungum B, Bjørngaard JH, Buland T. Psykisk helse i skolen. Effektevaluering av opplæringsprogrammene, Hva er det med Monica?, STEP - ungdom møter ungdom og Venn1.no. A1491. Sintef 2010. http://www.sintef.no/upload/Teknologi_samfunn/Rapport\%20A14919\%20Psykisk\%20 helse \%20i\%20skolen\%20-\%20Sluttrapport.pdf.

55. Wang CE, Skre I, Lindekleiv Magnus RE. Alle har en psykisk helse. Oppsummering etter en treårig effektevaluering gjennomført av Institutt for psykologi ved Universitetet i Tromsø. 2008.

56. Tobiassen AG, Magnus RE, Slettli Gundersen L. Alle har en psykisk helse: effektevaluering av en tredelt undervisningspakke for ungdomsskoletrinnet, 2. del, Self-efficacy og mestring. Universitetet i Tromsø, 2006.

57. Arnesen Y, Breivik C, Johnsen LI. Alle har en psykisk helse: effektevaluering av en tredelt undervisningspakke for ungdomsskoletrinnet: første del. Universitetet i Tromsø, 2005.

58. Andersen BJ, Nord E. Effekter av program i skolen for å forebygge psykiske plager. Norsk Epidemiologi $2010 ; 20$ (1): 15-22. 